\title{
Petrografia i granulometria utworów czerwonego spągowca - wstępna charakterystyka do poszukiwania złóż gazu zamkniętego (tight gas)
}

\begin{abstract}
Utwory czerwonego spągowca, ze względu na obecne w nich złoża gazu, są od dziesięcioleci przedmiotem intensywnych badań geologicznych. Współcześnie obszar występowania tych utworów (dotychczas kojarzony ze złożami konwencjonalnymi) budzi zainteresowanie również pod kątem złóż niekonwencjonalnych (ang. tight gas). W artykule przedstawiono wyniki badań petrograficznych i granulometrycznych dla ponad 400 próbek, które przyporządkowane zostały facjom: eolicznej, fluwialnej, plai (jeziornej) oraz tzw. białego spągowca. W celu zbadania relacji pomiędzy składnikami szkieletu ziarnowego, spoiwami a rozkładem uziarnienia dokonano analizy korelacyjnej. Uzyskane wyniki powiązać będzie można z rezultatami analiz petrofizycznych (porowatość, przepuszczalność), co ułatwi stworzenie cyfrowych modeli 3D i umożliwi lokalizację potencjalnych złóż gazu.
\end{abstract}

Słowa kluczowe: czerwony spągowiec, gaz zamknięty, petrografia, granulometria, facje.

\section{Petrography and granulometry of the Polish Rotliegend sandstones - preliminary characteristics for tight gas exploration}

\begin{abstract}
Rotliegend sandstones are well known conventional gas reservoirs and have been a subject of intense geological investigation for decades. Nowadays, even more attention is paid to Rotligend sandstones as they may also be reservoirs for unconventional gas - tight gas. This paper presents the results of petrographic and granulometric analyses for over 400 samples that have been described as sediments related to aeolian, fluvial, playa and so called "white Rotliegend" deposition systems. In order to investigate the relationships between the components of grains, cements and particle size distributions, correlation analysis was performed. Presented results may be directly linked with petrophysical (porosity, permeability) features of analyzed rocks, which enables to create detailed, digital 3D models of Rotliegend sediments. These models are powerful tools that can be used to locate new wells and new areas of interest.
\end{abstract}

Key words: Rotliegend, tight gas, petrography, granulometry, facies.

\section{Cel badań}

Utwory czerwonego spągowca, ze względu na obecne w nich złoża gazu, są od dziesięcioleci przedmiotem intensywnych badań geologicznych (sedymentologicznych) [3, 5, $10-12,16,18,22,29,34]$, petrograficznych [1, 7-9, 13-15, $17,20,21,25-27,30,35]$ oraz petrofizycznych [2, 4, 23, $24,31]$. Wciąż rosnące potrzeby energetyczne wymuszają nowe spojrzenie na poszukiwanie złóż gazu i zwrócenie uwagi na złoża niekonwencjonalne, w szczególności typu $t i$ ght gas. Współczesne osiągnięcia na polu poszukiwań ropy i gazu umożliwiają efektywniejsze wykorzystanie danych $\mathrm{z}$ badań laboratoryjnych poprzez ich implementację w cyfrowych modelach systemów naftowych, pozwalających nie tylko na wizualizację 3D obiektów złożowych, ale również na odtworzenie historii generacji i migracji węglowodorów. Efekty modelowania wpływają na pełniejsze zrozumienie procesów zachodzących w czasie geologicznym, jednocześnie wskazując na związki czasowo-przestrzenne pomiędzy skałami macierzystymi a zbiornikowymi. 
Niniejsze opracowanie jest zestawieniem oraz interpretacją danych petrograficznych i granulometrycznych, pochodzących z analiz utworów czerwonego spągowca, i ma na celu, poprzez odniesienie się do wydzieleń facjalnych, stworzenie bazy danych (oraz zależności między nimi), którą wykorzystać będzie można do korelacji z parametrami petrofizycz- nymi, takimi jak np. porowatość czy przepuszczalność. Wynik połączenia puli danych petrograficznych z petrofizycznymi w efektywny sposób posłuży do opracowania szeregu różnego rodzaju modeli (np. model kompakcji) i pozwoli na zlokalizowanie miejsc, w których można spodziewać się złóż gazu (zwłaszcza niekonwencjonalnych typu tight gas).

\section{Materiał badawczy}

Charakterystykę petrograficzną piaskowców czerwonego spągowca oparto na wynikach analizy planimetrycznej, wykonanej dla 408 próbek pochodzących z 32 odwiertów. Natomiast $\mathrm{w}$ przypadku analizy granulometryczej wykorzystano wyniki badań dla 495 próbek z 42 otworów. Dla większości próbek dysponowano kompletem wyników petrograficznych i granulometrycznych. Analizę planimetryczną i granulometryczną wykonano przy użyciu mikroskopu optycznego Nikon Eclipse LV100 POL, połączonego z cyfrową kamerą i zestawem komputerowym z zainstalowanym oprogramowaniem do cyfrowej analizy obrazu NIS-Elements BR 3.0. Obszar badań, wraz z naniesionymi wydzieleniami facjalnymi utworów czerwonego spągowca, przedstawiono na rysunku 1 .
W obrębie analizowanych próbek wyróżniono szereg typów litologicznych. Są to głównie arenity (kwarcowe, subarkozowe, sublityczne i lityczne), a rzadziej bogatsze w ilasto-żelazistą matriks waki (kwarcowe, subarkozowe i sublityczne). Każda z próbek przyporządkowano odpowiadającemu jej środowisku sedymentacyjnemu. Większość (niemal 75\%) próbek stanowily arenity i waki o genezie eolicznej (tablica 1). Stosunkowo wysoki udział w badanym materiale miały także skały przypisane facji utworów fluwialnych (około 17\%), rzadziej natomiast opisywano utwory facji jeziornej (plaja, około 3\%) czy też tzw. białego spągowca (około 5\%).

Spośród różnorodnych typów litologicznych (tablica 2) najliczniejszą grupę stanowią arenity $(89 \%)$, podczas gdy waki są dużo rzadsze (11\%). W obrębie arenitów dominują

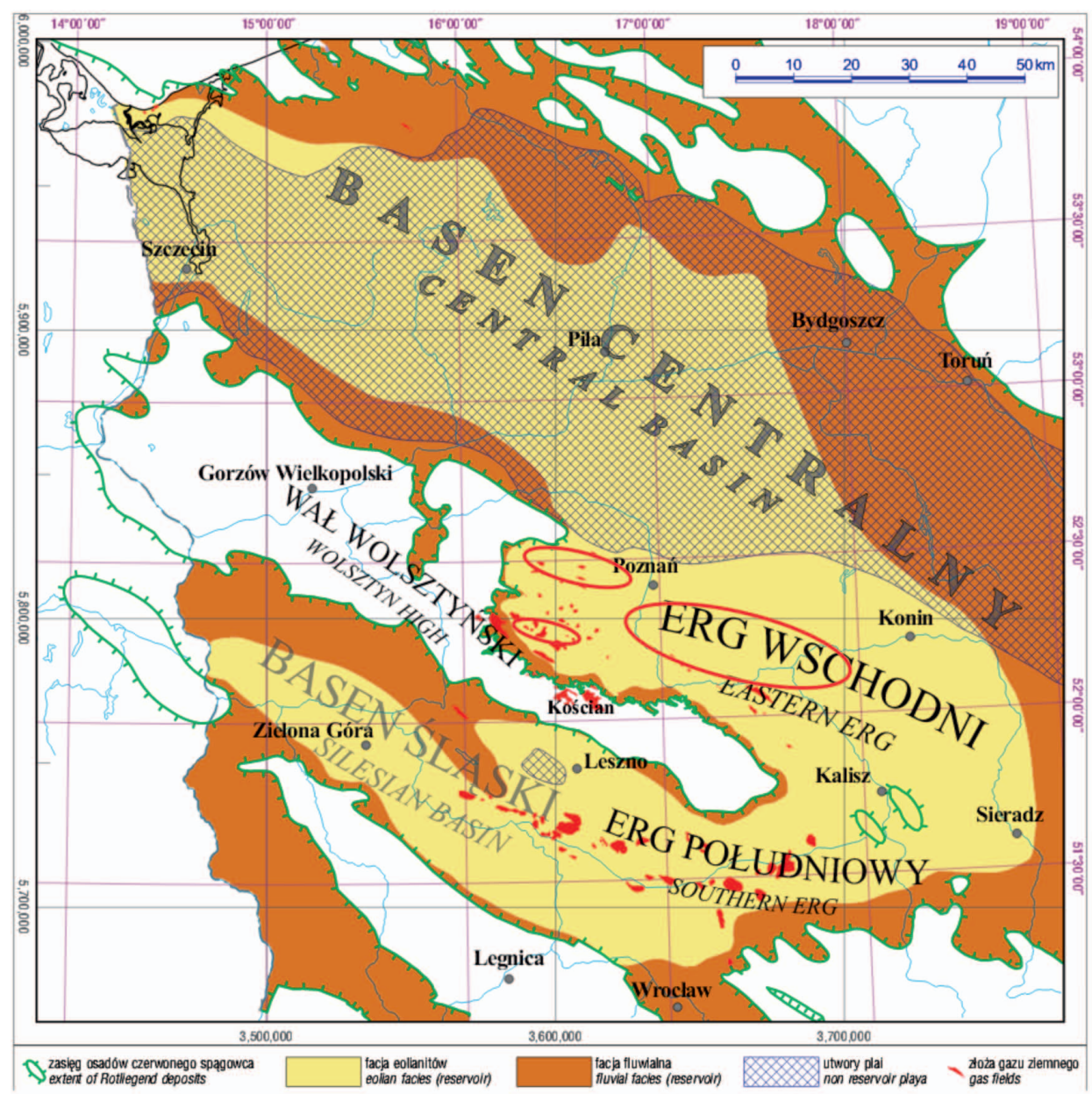

Rys. 1. Utwory czerwonego spągowca na terenie Polski [28] 
Tablica 1. Przebadane próbki w kontekście przynależności facjalnej

\begin{tabular}{|l|c|c|}
\hline \multicolumn{1}{|c|}{ Facje } & Liczba próbek & Udział \% \\
\hline Eoliczne & 304 & 74,51 \\
\hline Fluwialne & 70 & 17,16 \\
\hline Biały spągowiec & 22 & 5,39 \\
\hline Plaja & 12 & 2,94 \\
\hline
\end{tabular}

arenity sublityczne i subarkozowe, natomiast arenity kwarcowe i lityczne występują znacznie rzadziej. W obrębie wak wyróżnia się głównie waki sublityczne i subarkozowe, pobocznie spotykane są waki kwarcowe.
Tablica 2. Typy litologiczne w obrębie przebadanych próbek

\begin{tabular}{|l|c|r|r|}
\hline \multicolumn{1}{|c|}{ Litologia } & Liczba próbek & \multicolumn{2}{c|}{ Udział \% } \\
\hline Arenity kwarcowe & 40 & 9,78 & \\
\cline { 1 - 3 } Arenity sublityczne & $161,5^{*}$ & 39,49 & \multirow{2}{*}{88,51} \\
\hline Arenity lityczne & 31 & 7,58 & \\
\cline { 1 - 3 } Arenity subarkozowe & $129,5^{*}$ & 31,66 & \\
\hline Waki kwarcowe & 7 & 1,71 & \multirow{2}{*}{11,49} \\
\cline { 1 - 2 } Waki sublityczne & 20 & 4,89 & \\
\hline Waki subarkozowe & 20 & 4,89 & \\
\cline { 1 - 3 }
\end{tabular}

* W niezwykle rzadkiej sytuacji, gdy punkt na wykresie klasyfikacyjnym wypadał na granicy dwóch typów litologicznych, w ujęciu ilościowym podzielono go na pół i dodano do obu typów litologicznych.

\section{Szkielet ziarnowy}

Szkielet ziarnowy analizowanych skał jest zbudowany z ziaren o frakcji od gruboziarnistego pyłu do średnioziarnistego piasku. Ziarna wykazują zmienny stopień obtoczenia: od ostrokrawędzistych do dobrze obtoczonych. Szkielet ziarnowy jest zwarty, tekstura - najczęściej bezładna, aczkolwiek gdzieniegdzie obserwuje się charakterystyczne laminy grubszego materiału w obrębie frakcji drobniejszej.

W składzie szkieletu ziarnowego dominuje kwarc

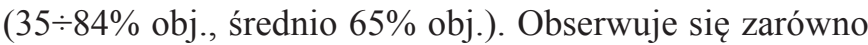
ziarna kwarcu monokrystalicznego $(33 \div 77 \%$ obj., średnio $57 \%$ obj.), jak i polikrystalicznego (do 19\% obj., średnio 8\% obj.). Część ziaren kwarcu posiada cechy wskazujące na ich pochodzenie ze skał metamorficznych oraz wulkanicznych.

Drugim istotnym składnikiem szkieletu ziarnowego są litoklasty. Wśród okruchów skał spotyka się zarówno skały magmowe, jak i metamorficzne oraz osadowe. Udział litoklastów jest bardzo zmienny i może osiągać nawet 35\% obj. (średnio $8 \%$ obj.). Wśród okruchów skał magmowych można znaleźć zarówno skały głębinowe (różnego rodzaju granitoidy), jak i wylewne (ryolity, dacyty). Skały metamorficzne reprezentowane są przez łupki kwarcowo-łysz- czykowe i kwarcyty, natomiast wśród okruchów skał osadowych obecne są piaskowce drobnoziarniste, mułowce oraz iłowce. Spośród litoklastów najczęściej obserwuje się skały wulkaniczne (do $32 \%$ obj., średnio $4,5 \%$ obj.) oraz głębinowe (do 19\% obj., średnio 3\% obj.). Skały metamorficzne (do 3\% obj., średnio $0,17 \%$ obj.) oraz osadowe (do 6\% obj., średnio $0,5 \%$ obj.) są rzadziej spotykane.

Oprócz kwarcu i litoklastów w szkielecie ziarnowym badanych arenitów i wak stosunkowo często obserwuje się ziarna skaleni. Są to zarówno skalenie potasowe (mikroklin), jak również plagioklazy (albit, oligoklaz). Udział skaleni nie przekracza $11 \%$ obj., osiągając średnią zawartość w analizowanych próbkach na poziomie około $4 \%$ obj. Skalenie dość wyraźnie dotknięte są procesem serycytyzacji. Część ziaren uległa także częściowemu lub całkowitemu rozpuszczeniu, przyczyniając się do rozwoju wtórnej porowatości.

W analizowanych skałach spotyka się również łyszczyki (muskowit) oraz minerały akcesoryczne (cyrkon, turmalin, apatyt) i nieprzeźroczyste (tlenki żelaza). Są one dość częste, aczkolwiek występują w bardzo niewielkich ilościach.

\section{Spoiwo}

W przestrzeni porowej analizowanych skał zauważyć można szereg różnego typu spoiw. Są to w głównej mierze: ilasto-żelazista matriks oraz cementy: ilasty, węglanowy, siarczanowy oraz kwarcowy.

Matriks ilasto-żelazista jest mieszaniną pyłu kwarcowego z minerałami ilastymi (illit) i związkami żelaza. Spoiwo tego typu obserwuje się w porach. Może ono również tworzyć cienkie obwódki na ziarnach detrytycznych. Matriks jest stosunkowo powszechna, a jej zawartość w nielicznych przypadkach dochodzić może nawet do $38 \%$ obj. (przy czym średni udział jest na poziomie $7 \% \mathrm{obj}$.).
Poza detrytycznym materiałem ilastym w badanych skałach obecne są również autigeniczne minerały ilaste, przede wszystkim illit i chloryt. Illit wykształcony jest w postaci drobnych łuseczek i włókien. Często tworzy obwódki na ziarnach detrytycznych, może również zarastać przestrzeń porową. Chloryty obecne są w postaci blaszek mogących tworzyć skupienia lub bardzo cienkie obwódki na ziarnach detrytycznych. Udział autigenicznych minerałów ilastych nie przekracza 14,5\% obj., przy czym średnio jest ich dużo mniej, tj. około $1,5 \%$ obj.

Bardzo istotnym składnikiem spoiwa są cementy węglanowe. Wyróżnia się tu cement kalcytowy oraz dolomitowy. 
Cement kalcytowy najczęściej występuje jako wypełnienia porów, może on również częściowo zastępować mniej stabilne chemicznie ziarna, takie jak skalenie czy okruchy skał wulkanicznych. Obserwowane kalcyty mogą zawierać domieszki manganu i dwuwartościowego żelaza. Dolomit wykształcony jest w postaci romboedrów, wypełniających pory w stosunkowo niewielkim stopniu. Udział węglanów w badanych próbkach może sięgać $41 \%$ obj., przy czym najczęściej jest on znacznie niższy (średnio 9,5\% obj.).

Kolejnym typem spoiwa są cementy siarczanowe. Najczęściej spotykany jest anhydryt, wypełniający pory w sposób podobny do kalcytu.

Zawartość anhydrytu w badanych profilach jest stosunkowo niska (średnio $1 \%$ obj.), aczkolwiek w przypadku niektórych próbek (zwłaszcza w przystropowych partiach badanych profili) jego udział może zostać znacząco zwiększony i sięgać nawet do $23 \%$ obj., co prawdopodobnie związane jest $\mathrm{z}$ infiltracją wód cechsztyńskich.

Ostatnim typem cementu, który występuje w badanych próbkach, jest autigeniczny kwarc. Obecny jest on w postaci niepełnych obwódek na detrytycznych ziarnach lub też jako wypełnienie porów. Jego udział sięga maksymalnie $21 \%$ obj., przy czym najczęściej jest znacznie niższy i wynosi średnio 3,5\% obj.

Średnie udziały głównych składników szkieletu ziarnowego w odniesieniu do wydzieleń facjalnych przedstawiono na rysunku 2. Generalnie nie zaznaczają się żadne istotne różnice w składzie mineralnym w obrębie różnych facji, z kilkoma wyjątkami. Oto one:

- wśród osadów fluwialnych obserwuje się zdecydowanie zwiększony udział litoklastów skał magmowych (wulkanicznych i głębinowych). Średnia zawartość litoklastów, wynosząca około $17 \%$ obj., jest tu wyższa od średniego udziału tych składników w innych facjach, gdzie mieszczą się one w przedziale $2,5 \div 7 \%$ obj.;

- udział ilasto-żelazistej matriks jest zdecydowanie większy w osadach jeziornych (plaja), osiągając średnią zawartość na poziomie $17 \%$ obj. Wartość ta jest wyraźnie wyższa w porównaniu z innymi facjami, gdzie średni udział matriks nie przekracza $8 \%$ obj.;

- osady facji białego spągowca wyróżniają się na tle innych największą średnią zawartością siarczanów (około $3,5 \%$ obj.), a także najmniejszym średnim udziałem matriks (rzędu 3\% obj.) oraz cementu kwarcowego ( $<1,5 \%$ obj.). Analizowane próbki charakteryzują się zmiennym udziałem porowatości - od bliskiej zeru do $20,5 \%$ obj. (średnio $6 \%$ obj.). Największą średnią porowatość zaobserwowano w próbkach facji białego spągowca i facji eolicznej (odpowiednio:
8 i 7\% obj.), najmniejszą natomiast $(<1 \%$ obj.) dla utworów plai. Porowatość wykształcona jest jako pory, szczeliny obserwuje się rzadko i są najczęściej pojedyncze, nie tworzą rozbudowanych systemów. Ciekawym zjawiskiem, związanym z wkładkami (laminami) grubszego materiału w obrębie drobniejszych ziaren, jest obecność tzw. pseudoszczelin, czyli stref o podwyższonej porowatości, przypominających szczeliny, a w rzeczywistości będących połączonymi ze sobą dużymi porami.

Udział porowatości i cementów dla wszystkich próbek w wydzielonych przedziałach przedstawiają rysunki 3 i 4 . Wśród przebadanych skał najliczniej reprezentowane są te, których porowatość nie przekracza 5\% obj. $(49,5 \%)$, nato-

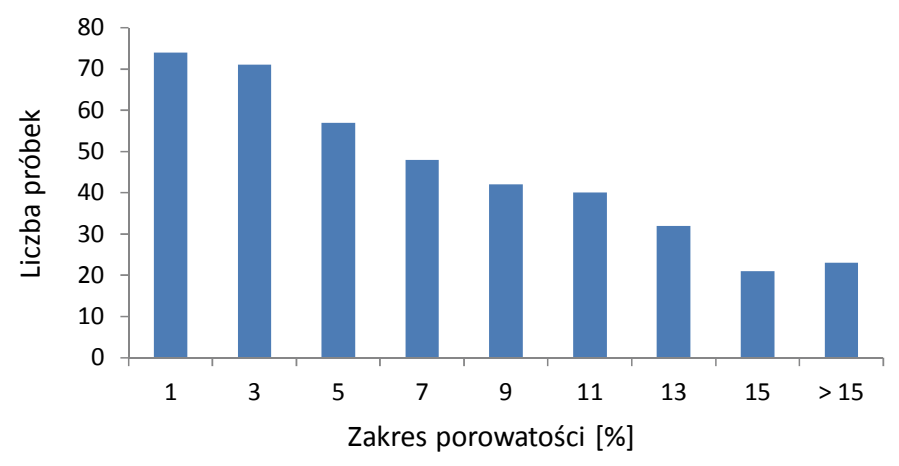

Rys. 3. Udział porowatości w przebadanych próbkach

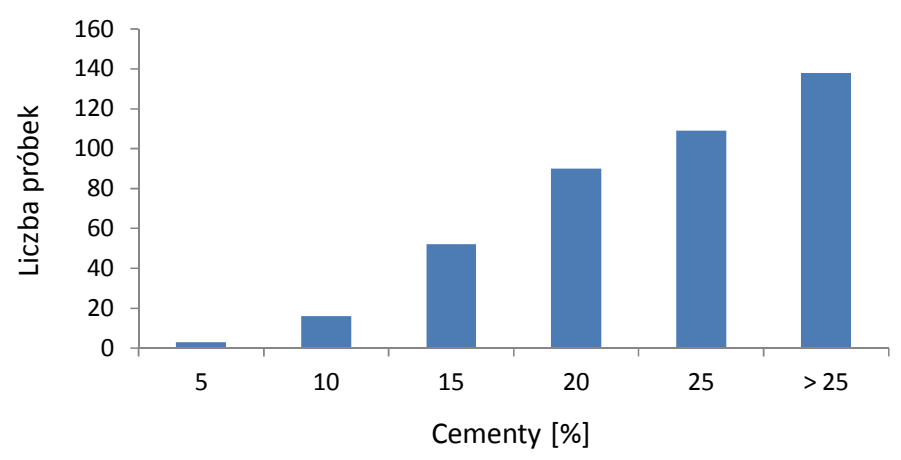

Rys. 4. Udział cementów w przebadanych próbkach 
miast próbki o wysokich porowatościach (powyżej 15\%) stanowią jedynie 5,5\%. Suma spoiw w przebadanych prób- kach jest przeważnie większa niż $20 \%$ obj. (60,5\% wszystkich próbek).

\section{Diageneza}

Analizowane skały ulegały procesom diagenetycznym (kompakcja, cementacja, rozpuszczanie, zastępowanie, przeobrażanie), spośród których na redukcję pierwotnej porowatości największy wpływ miały kompakcja i cementacja. Kompakcja doprowadziła do zwiększenia upakowania okruchów w szkielecie ziarnowym, natomiast cementacja ograniczyła przestrzeń porową poprzez kształtowanie się szeregu różnych typów cementów, m.in. ilastego, kwarcowego, węglanowego czy anhydrytowego. Powstanie tych cementów związane jest $\mathrm{z}$ infiltracją wód gruntowych i atmosferycznych.

O ile kompakcja zachodziła od samego po-

czątku lityfikacji i trwała nieprzerwanie, o tyle cementacja jest wyraźnie etapowa i nierozerwalnie związana ze zmieniającymi się warunkami temperaturowo-ciśnieniowymi.

Wydaje się, iż jako pierwsze wytworzyły się obwódki ilasto-żelaziste, co jest wynikiem infiltracji wód niosących zawiesinę minerałów ilastych i żelazistych, której stałe składniki odkładały się na ziarnach detrytycznych. Wody te mogły zawierać również krzemionkę, która wytrącała się w postaci obwódek na ziarnach lub bezpośrednio w porach. Jej źródłem na późniejszym etapie diagenezy mogły być również minerały, które uległy rozpuszczaniu, tj. łyszczyki, skalenie, a także okruchy skalne [15]. Ten sam proces mógł doprowadzić do krystalizacji chlorytu i smektytu. Wraz ze wzrostem temperatury i ciśnienia proces rozpuszczania ulegał coraz większej intensyfikacji, a jego finalnym efektem jest krystalizacja illitu. Krystalizacja cementów węglanowych (zarówno kalcytu, jak i dolomitu) odbywała się na kilku etapach diagenezy, zaczynając od jej wczesnej fazy, a na późnej kończąc.

Schematycznie etapy tworzenia się różnego rodzaju spoiw i ich kolejność przedstawiono na rysunku 5.

W obrębie badanych próbek na utratę pierwotnej porowatości (w przeważającej ilości przypadków) większy wpływ miała kompakcja niż cementacja. Proces kompakcji jest dominujący dla $68 \%$ próbek, podczas gdy cementacja przeważa jedynie w co trzeciej próbce. Współczynnik COPL (utrata pierwotnej porowatości w wyniku kompakcji) wynosi od 2 do 39\% (średnio 23\%). Parametr CEPL (utrata pierwotnej porowatości w wyniku cementacji) zawiera się w podobnym zakresie: od 2 do $38 \%$, jednak jego średnia wartość jest niższa i wynosi 17\%. Współczynnik kompakcji (ICOMPACT) zawiera się w szerokim przedziale: od 7 do $95 \%$, przy średniej wartości 56\%. Zmienność wyżej wymienionych parametrów w odniesieniu do facji ujęto w tablicy 3 , natomiast udział cementów oraz porowatości w badanych skałach przedstawia rysunek 6 oraz tablica 4 .

Tablica 3. Parametry CEPL, COPL oraz ICOMPACT w odniesieniu do wydzielonych facji

\begin{tabular}{|l|c|c|c|c|}
\hline \multirow{2}{*}{ Facje } & CEPL [\%] & COPL [\%] & ICOMPACT & \multicolumn{1}{|c|}{} \\
\hline \multirow{4}{*}{ Eoliczne } & 2,56 & 1,79 & 0,07 & min. \\
\cline { 2 - 5 } & 37,67 & 38,36 & 0,94 & maks. \\
\cline { 2 - 5 } & 17,79 & 21,75 & 0,55 & średnia \\
\hline \multirow{4}{*}{ Fluwialne } & 2,26 & 4,65 & 0,13 & min. \\
\cline { 2 - 5 } & 34,16 & 39,38 & 0,95 & maks. \\
\cline { 2 - 5 } & 15,02 & 27,71 & 0,65 & średnia \\
\hline \multirow{4}{*}{ Plaja } & 12,86 & 6,14 & 0,14 & min. \\
\cline { 2 - 5 } & 38,20 & 31,25 & 0,71 & maks. \\
\cline { 2 - 5 } & 25,65 & 18,58 & 0,42 & średnia \\
\hline \multirow{3}{*}{$\begin{array}{l}\text { Biały } \\
\text { spągowiec }\end{array}$} & 6,31 & 6,62 & 0,20 & min. \\
\cline { 2 - 5 } & 26,33 & 30,99 & 0,83 & maks. \\
\cline { 2 - 5 } & 16,54 & 22,28 & 0,57 & średnia \\
\hline
\end{tabular}

Analiza procesów kompakcji i cementacji w odniesieniu do facji pozwoliła stwierdzić, iż wpływ obu tych czynników jest różny w zależności od środowiska sedymentacji. Facja utworów fluwialnych charakteryzuje się wyraźną dominacją kompakcji nad cementacją (rysunek 7) - współczynnik COPL jest dla $82 \%$ próbek większy od parametru CEPL, co więcej, jego średnia wartość jest najwyższa i wynosi blisko $28 \%$. Od- 


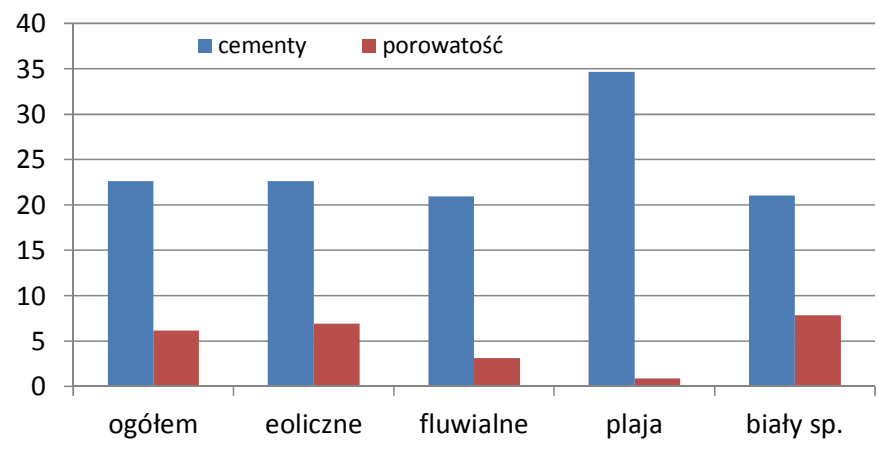

Rys. 6. Udział cementów oraz porowatości $\mathrm{w}$ odniesieniu do facji

Tablica 4. Udział cementów oraz porowatości w odniesieniu do wydzielonych facji

\begin{tabular}{|l|c|r|c|}
\hline \multicolumn{1}{|c|}{ Facje } & Cementy [\%] & Pory [\%] & \multicolumn{1}{|c|}{} \\
\hline \multirow{3}{*}{ Eoliczne } & 4,07 & 0,00 & min. \\
\cline { 2 - 4 } & 47,32 & 20,00 & maks. \\
\cline { 2 - 4 } & 22,64 & 6,90 & średnia \\
\hline \multirow{4}{*}{ Fluwialne } & 3,72 & 0,00 & min. \\
\cline { 2 - 4 } & 54,50 & 12,89 & maks. \\
\cline { 2 - 4 } & 20,94 & 3,11 & średnia \\
\hline \multirow{3}{*}{ Plaja } & 18,70 & 0,00 & min. \\
\cline { 2 - 4 } & 62,00 & 3,50 & maks. \\
\cline { 2 - 4 } & 34,67 & 0,88 & średnia \\
\hline \multirow{3}{*}{$\begin{array}{l}\text { Biały } \\
\text { spągowiec }\end{array}$} & 9,10 & 0,00 & min. \\
\cline { 2 - 4 } & 31,20 & 20,40 & maks. \\
\cline { 2 - 4 } & 21,04 & 7,83 & średnia \\
\hline
\end{tabular}
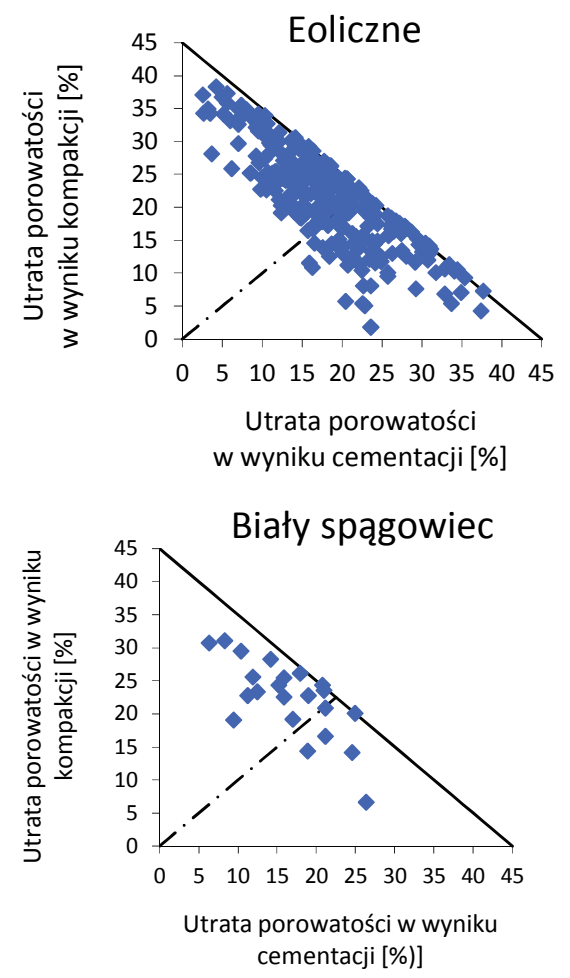

Eoliczne
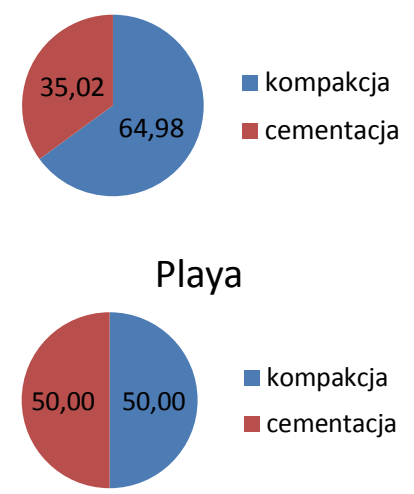

Fluwialne

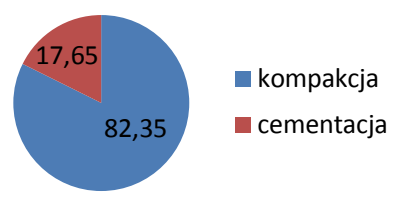

Biały spągowiec

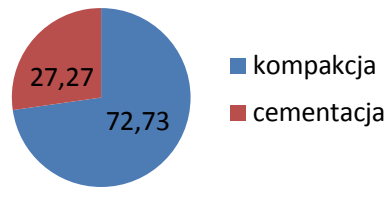

Rys. 7. Udział próbek, w których zaobserwowano dominację procesów kompakcji bądź cementacji w odniesieniu do facji

wrotną sytuację obserwuje się dla utworów plai, gdzie udział próbek z dominacją kompakcji nad cementacją jest najniższy (zaledwie 50\%), za to średnia wartość parametru CEPL jest najwyższa (około 26\%). Facje utworów eolicznych oraz białego spągowca są do siebie zbliżone, biorąc pod uwagę wpływ kompakcji i cementacji - który nie jest tak charakterystyczny, jak w przypadku utworów facji fluwialnej i plai.

Wpływ kompakcji i cementacji na redukcję pierwotnej porowatości przedstawiono na rysunku 8 [19]. Pierwotna porowatość stosunkowo dobrze zachowana się w utworach eolicznych i białego spągowca.
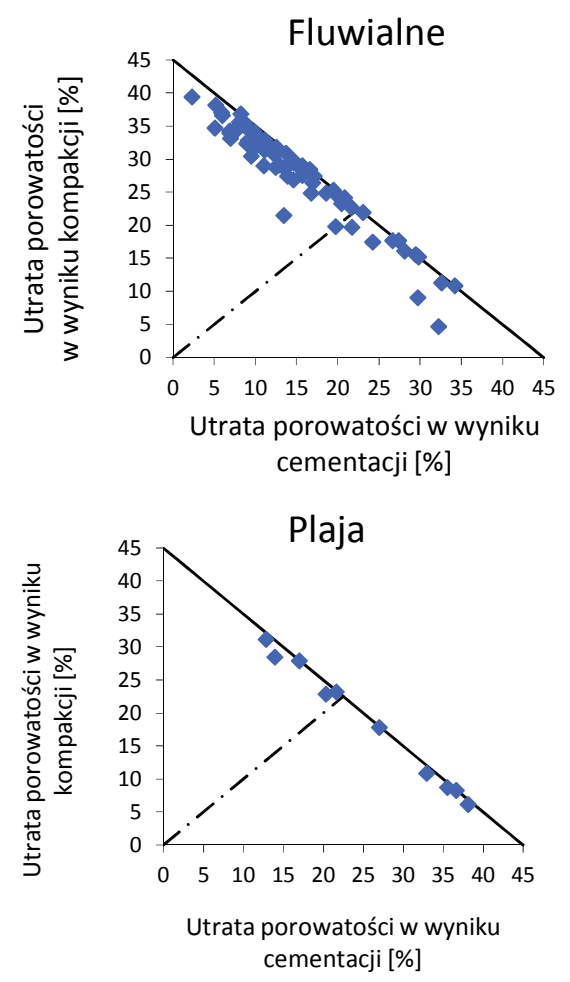

Rys. 8. Wpływ kompakcji i cementacji na utratę pierwotnej porowatości w odniesieniu do wydzielonych facji [19] 


\section{Analiza granulometryczna}

Analiza granulometryczna przeprowadzona została na płytkach cienkich. Dla każdej próbki zmierzono 350 średnic ziaren, co pozwoliło na wyliczenie podstawowych parametrów granulometrycznych i zakwalifikowanie ich do odpowiednich przedziałów zmienności $[6,32,33]$. Posłużono się następującymi wzorami [6]:

średnia średnica:

$$
G S S=\frac{\Phi_{16}+\Phi_{50}+\Phi_{84}}{3}
$$

wysortowanie:

$$
G S O=\frac{\Phi_{84}-\Phi_{16}}{4}+\frac{\Phi_{95}-\Phi_{5}}{6,6}
$$

skośność:

$$
G S K=\frac{\Phi_{16}+\Phi_{84}-2 \Phi_{50}}{2\left(\Phi_{84}-\Phi_{16}\right)}+\frac{\Phi_{5}+\Phi_{95}-2 \Phi_{50}}{2\left(\Phi_{95}-\Phi_{5}\right)}
$$

spłaszczenie:

$$
G S P=\frac{\Phi_{95}-\Phi_{5}}{2,44\left(\Phi_{75}-\Phi_{25}\right)}
$$

gdzie:

$\Phi_{5}, \Phi_{16,} \Phi_{50}, \Phi_{75}, \Phi_{84}, \Phi_{95}$ - percentyle rozkładu uziarnienia, odczytane z krzywej kumulacyjnej.

Przebadane skały reprezentują wszystkie opisane w części petrograficznej facje, tj. utwory eoliczne, fluwialne, jeziorne (plaja) oraz tzw. biały spągowiec. Najliczniejsze są osady wydmowe (eoliczne). Stanowią one ponad $80 \%$ ogółu skał, natomiast druga, zdecydowanie mniej licznie reprezentowaną facją (12\%), są utwory białego spągowca.

Wśród przeanalizowanych próbek dominują piaskowce średnioziarniste $(48,5 \%)$ oraz drobnoziarniste $(49,7 \%)$, podczas gdy inne granulacje nie przekraczają $1 \%$. Graficzna średnia średnica (GSS) przyjmuje wartości od 1,55 do $4,58 \varphi$.

Stopień wysortowania (parametr graficznego średniego odchylenia, będacy miara rozproszenia wartości średnic ziaren - GSO) w połowie przebadanych próbek jest umiar- kowanie dobry. Dość znaczny udział mają również próbki o umiarkowanym $(21,8 \%)$ oraz dobrym $(26 \%)$ stopniu wysortowania, a zdecydowanie mniej liczne są próbki, gdzie parametr ten odpowiada słabemu wysortowaniu $(1,8 \%)$. Ogółem GSO zawiera się w zakresie od 0,357 do 1,308.

Graficzna skośność (GSK, miara asymetrii rozkładu) w obrębie analizowanych skał przyjmuje wartości zarówno dodatnie, jak i ujemne (od -0,52 do 0,32). Przebadane próbki charakteryzują się w przeważającej mierze (56\%) w przybliżeniu symetrycznym rozkładem uziarnienia. Zdecydowanie mniej jest próbek, w których zanotowano rozkład skośnie ujemny lub skośnie dodatni, a jedynie wyjątkowo pojawiają się przypadki, gdzie rozkład uziarnienia jest skośny bardzo ujemnie lub bardzo dodatnio.

Analiza graficznego spłaszczenia (GSP, miara zagęszczenia wyników wokół wartości centralnej) w obrębie badanych skał wskazuje, że analizowane próbki wykazują głównie mezokurtyczny $(60,4 \%)$ rozkład uziarnienia. Rozkłady leptokurtyczne i platykurtyczne są rzadsze (odpowiednio: 22,8 oraz $15 \%)$, natomiast sporadycznie $(1,8 \%)$ obserwuje się rozkład bardzo leptokurtyczny.

Interesujące jest porównanie podstawowych parametrów granulometrycznych w stosunku do przynależności facjalnej. Parametr średniej średnicy w przypadku utworów eolicznych odpowiada w głównej mierze utworom zarówno drobno- jak i bardzo drobnoziarnistym (po około 49\%). Utwory bardzo drobnoziarniste zdecydowanie dominują w facji

Tablica 5. Udział procentowy próbek w odniesieniu do klas wielkości ziaren w obrębie wydzielonych facji

\begin{tabular}{|l|c|c|c|c|}
\cline { 2 - 5 } \multicolumn{1}{c|}{} & \multicolumn{3}{c|}{ Klasa } & Pył \\
\cline { 2 - 5 } & \multicolumn{3}{c|}{ Piasek } \\
\cline { 2 - 5 } & średnioziarnisty & drobnoziarnisty & bardzo drobnoziarnisty & gruboziarnisty \\
\hline Eoliczne & 1,00 & $\mathbf{4 9 , 2 5}$ & $\mathbf{4 9 , 7 5}$ & 0,00 \\
\hline Fluwialne & 0,00 & 11,11 & $\mathbf{8 3 , 3 3}$ & 5,56 \\
\hline Plaja & 0,00 & 0,00 & $\mathbf{7 1 , 4 3}$ & 28,57 \\
\hline Biały spągowiec & 0,00 & $\mathbf{6 5 , 5 7}$ & 34,43 & 0,00 \\
\hline
\end{tabular}

Tablica 6. Udział procentowy próbek o różnym stopniu wysortowania w odniesieniu do facji

\begin{tabular}{|l|c|c|c|c|}
\cline { 2 - 5 } \multicolumn{1}{c|}{} & \multicolumn{4}{c|}{ Stopień wysortowania } \\
\cline { 2 - 5 } \multicolumn{1}{c|}{} & dobry & umiarkowanie dobry & umiarkowany & słaby \\
\hline Eoliczne & 23,63 & $\mathbf{4 9 , 2 5}$ & 24,88 & 2,24 \\
\hline Fluwialne & $\mathbf{4 4 , 4 4}$ & $\mathbf{5 0 , 0 0}$ & 5,56 & 0,00 \\
\hline Plaja & 21,43 & $\mathbf{7 1 , 4 3}$ & 7,14 & 0,00 \\
\hline Biały spągowiec & $\mathbf{3 9 , 3 4}$ & $\mathbf{5 0 , 8 2}$ & 9,84 & 0,00 \\
\hline
\end{tabular}


fluwialnej oraz jeziornej (plaja), gdzie osiągają odpowiednio: $83 \%$ i $71 \%$. Większe średnice (utwory drobnoziarniste) przeważają natomiast $\mathrm{w}$ przypadku utworów białego spągowca $(65 \%)$ - tablica 5 .

Utwory eoliczne wykazują przewagę skał o umiarkowanie dobrym stopniu wysortowania (49\%), przy czym próbki o dobrym i umiarkowanym wysortowaniu również występują dość licznie (około 25\%). Utwory fluwialne są przeważnie dobrze (44\%) bądź umiarkowanie dobrze $(50 \%)$ wysortowane, co jest wynikiem zbliżonym do utworów białego spągowca (dobrze wysortowane - 39\%, umiarkowanie dobrze - 51\%). Wśród przebadanych próbek skały powstałe w środowisku jeziornym wykazują naj- większy udział ziaren umiarkowanie dobrze wysortowanych (71\%) - tablica 6.

W przypadku parametru skośności dla utworów eolicznych, plai oraz białego spągowca obserwuje się głównie w przybliżeniu symetryczny rozkład uziarnienia, a w mniejszym stopniu skośny ujemnie. Rozkład uziarnienia widoczny dla utworów fluwialnych jest nieco inny: dominuje skośny dodatnio i w przybliżeniu symetryczny, a rzadziej obserwuje się rozkład skośny ujemnie. Analiza spłaszczenia rozkładu uziarnienia w przypadku utworów eolicznych, fluwialnych i białego spągowca wskazuje na dominację rozkładu mezokurtycznego, a w przypadku utworów plai na przewagę rozkładu mezokurtycznego i leptokurtycznego.

\section{Korelacje petrograficzno-granulometryczne}

Spośród analizowanych próbek wybrano te, które posiadały komplet wyników jednocześnie: $\mathrm{z}$ analizy petrograficznej i granulometrycznej. Było to ogółem 208 próbek pochodzących z 23 odwiertów. Wykonano dla nich analizę korelacyjną, która uwzględniała składniki szkieletu ziarnowego (kwarc, skalenie, litoklasty, minerały akcesoryczne i nieprzeźroczyste), spoiwa (matriks, autigeniczne minerały ilaste, węglany, siarczany, autigeniczny kwarc), porowatość oraz parametry granulometryczne, takie jak: średnia średnica, wysortowanie, skośność oraz spłaszczenie. Wyniki korelacji przedstawiono w tabeli 8. Największe zależności (współczynnik korelacji $>0,5$ lub $<-0,5$ ) zaobserwowano dla kwarcu, matriks ilasto-żelazistej oraz parametrów średniej średnicy i wysortowania. Oto one:

- udział kwarcu maleje wraz ze wzrostem zawartości matriks ilasto-żelazistej (współczynnik korelacji-0,52),

- udział matriks ilasto-żelazistej rośnie wraz ze zmniejszaniem się średniej średnicy (współczynnik korelacji 0,63). Zauważalne zależności (współczynnik korelacji $>0,4$ lub $<-0,4)$ występują również pomiędzy kwarcem, skaleniami, litoklastami oraz średnią średnicą. I tak:

- porowatość rośnie wraz ze wzrostem udziału kwarcu (współczynnik korelacji 0,41),

- udział kwarcu zmniejsza się wraz ze spadkiem wielkości ziaren (współczynnik korelacji-0,48),

- udział skaleni jest powiązany z zawartością litoklastów (współczynnik korelacji 0,40),
- porowatość spada wraz ze wzrostem udziału węglanów. Spośród grupy próbek z kompletem wyników petrograficznych i granulometrycznych wyselekcjonowano te, które należą do facji eolicznej (w sumie 172 próbki) i przeprowadzono analizę korelacji tych samych parametrów co dla wszystkich próbek. Otrzymane wyniki przedstawiono w tablicy 9. Porównanie współczynników korelacji uzyskanych dla wszystkich próbek z otrzymanymi dla próbek należących do facji eolicznej zaprezentowano w tablicy 7. Przeważnie różnice nie są duże, za wyjątkiem zależności zawartości kwarcu od porowatości i średniej średnicy, gdzie współczynniki korelacji w przypadku próbek należących do facji eolicznej są niższe i wynoszą odpowiednio: 0,30 oraz $-0,32$.

Tablica 7. Porównanie wybranych współczynników korelacji uzyskanych dla wszystkich próbek i dla próbek należących do facji eolicznej

\begin{tabular}{|l|c|c|}
\cline { 2 - 3 } \multicolumn{1}{c|}{} & \multicolumn{2}{c|}{ Współczynnik korelacji } \\
\hline Zależności & wszystkie próbki & utwory eoliczne \\
\hline Kwarc - matriks & $-0,52$ & $-0,47$ \\
\hline Kwarc - porowatość & 0,41 & 0,30 \\
\hline Kwarc - średnia średnica & $-0,48$ & $-0,32$ \\
\hline Skalenie - litoklasty & 0,40 & 0,46 \\
\hline Matriks - średnia średnica & 0,63 & 0,60 \\
\hline Węglany - porowatość & $-0,45$ & $-0,45$ \\
\hline Wysortowanie - skośność & $-0,54$ & $-0,57$ \\
\hline
\end{tabular}

\section{Znaczenie uzyskanych wyników w poszukiwaniach złóż gazu}

Otrzymane wyniki stanowią bazę parametrów petrograficznych i granulometrycznych dla utworów czerwonego spągowca na stosunkowo dużym obszarze. Jest to podstawa, którą dość łatwo można skorelować z wynikami analiz petrofizycznych (piknometria helowa, porozymetria azotowa) i ustalić związki pomiędzy kluczowymi dla geologii naftowej parametrami, takimi jak porowatość i przepuszczalność, a wykształceniem petrograficznym, facjalnym oraz rozkładem uziarnienia. 
Tablica 8. Współczynniki korelacji parametrów petrograficznych i granulometrycznych dla wszystkich próbek

\begin{tabular}{|c|c|c|c|c|c|c|c|c|c|c|}
\hline & \multirow[b]{2}{*}{$\begin{array}{l}0 \\
\vdots \\
3 \\
\vdots\end{array}$} & \multirow[b]{2}{*}{$\frac{\mathscr{0}}{\frac{\mathbb{d}}{\sqrt[T]{n}}}$} & \multirow[b]{2}{*}{$\begin{array}{l}\frac{\partial}{0} \\
\frac{\mathbb{E}}{\sqrt{3}} \\
\frac{0}{0}\end{array}$} & \multirow{2}{*}{ 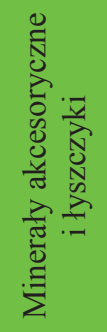 } & \multicolumn{5}{|c|}{ Spoiwo } & \multirow[b]{2}{*}{ iे } \\
\hline & & & & & 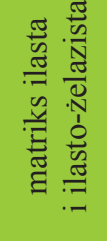 & 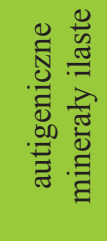 & $\begin{array}{l}\stackrel{\vec{\Xi}}{D} \\
\vec{\infty} \\
\overrightarrow{3}\end{array}$ & 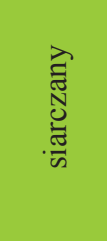 & 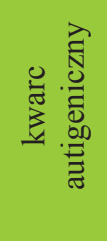 & \\
\hline Skalenie & $-0,14$ & $\mathrm{x}$ & & & & & & & & \\
\hline Litoklasty & $-0,22$ & 0,40 & $\mathrm{x}$ & & & & & & & \\
\hline Minerały akc. i niep., łyszczyki & $-0,22$ & $-0,07$ & $-0,07$ & $\mathrm{x}$ & & & & & & \\
\hline Matriks ilasta i ilasto-żelazista & $-0,52$ & $-0,16$ & $-0,11$ & 0,38 & $\mathrm{x}$ & & & & & \\
\hline Autigeniczne minerały ilaste & $-0,01$ & $-0,20$ & $-0,06$ & 0,08 & $-0,01$ & $\mathrm{x}$ & & & & \\
\hline Węglany & $-0,26$ & $-0,19$ & $-0,14$ & $-0,26$ & $-0,28$ & $-0,21$ & $\mathrm{x}$ & & & \\
\hline Siarczany & $-0,09$ & $-0,06$ & $-0,09$ & $-0,08$ & $-0,21$ & $-0,09$ & $-0,10$ & $\mathrm{x}$ & & \\
\hline Kwarc autigeniczny & $-0,26$ & 0,25 & 0,23 & 0,15 & $-0,12$ & 0,20 & $-0,26$ & $-0,04$ & $\mathrm{x}$ & \\
\hline Porowatość & 0,41 & 0,15 & 0,09 & 0,13 & $-0,03$ & 0,16 & $-0,45$ & $-0,17$ & $-0,09$ & $\mathrm{x}$ \\
\hline GSS & $-0,48$ & $-0,30$ & $-0,24$ & 0,22 & 0,63 & 0,12 & 0,08 & 0,00 & $-0,22$ & $-0,19$ \\
\hline GSO & 0,01 & 0,11 & 0,36 & $-0,01$ & $-0,01$ & $-0,06$ & $-0,03$ & $-0,19$ & 0,01 & $-0,14$ \\
\hline GSK & 0,22 & $-0,08$ & $-0,25$ & $-0,03$ & $-0,28$ & 0,06 & 0,06 & 0,16 & 0,03 & 0,09 \\
\hline GSP & $-0,19$ & 0,01 & 0,13 & 0,12 & 0,22 & $-0,04$ & $-0,09$ & $-0,06$ & 0,10 & $-0,11$ \\
\hline
\end{tabular}

Tablica 9. Współczynniki korelacji parametrów petrograficznych i granulometrycznych dla próbek należących do facji eolicznej

\begin{tabular}{|c|c|c|c|c|c|c|c|c|c|c|}
\hline & \multirow[b]{3}{*}{$\begin{array}{l}0 \\
\vdots \\
3 \\
\Delta\end{array}$} & \multirow[b]{3}{*}{$\frac{.0}{\frac{\pi}{\pi}}$} & \multirow[b]{3}{*}{ 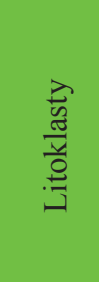 } & \multirow{3}{*}{ 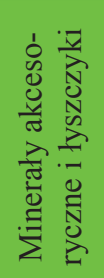 } & \multirow{2}{*}{\multicolumn{5}{|c|}{ Spoiwo }} & \multirow[b]{3}{*}{$\stackrel{\overrightarrow{0}}{0}$} \\
\hline & & & & & & & & & & \\
\hline & & & & & 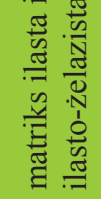 & 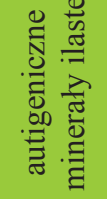 & 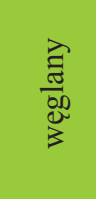 & 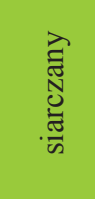 & 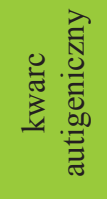 & \\
\hline Skalenie & $-0,21$ & $\mathrm{x}$ & & & & & & & & \\
\hline Litoklasty & $-0,32$ & 0,46 & $\mathrm{x}$ & & & & & & & \\
\hline Minerały akc. i niep., łyszczyki & $-0,17$ & $-0,07$ & 0,00 & $\mathrm{x}$ & & & & & & \\
\hline Matriks ilasta i ilasto-żelazista & $-0,47$ & $-0,15$ & $-0,08$ & 0,39 & $\mathrm{x}$ & & & & & \\
\hline Autigeniczne minerały ilaste & 0,07 & $-0,17$ & $-0,06$ & 0,05 & $-0,12$ & $\mathrm{x}$ & & & & \\
\hline Węglany & $-0,18$ & $-0,21$ & $-0,14$ & $-0,35$ & $-0,32$ & $-0,20$ & $\mathrm{x}$ & & & \\
\hline Siarczany & $-0,11$ & $-0,06$ & $-0,15$ & $-0,06$ & $-0,16$ & $-0,11$ & $-0,10$ & $\mathrm{x}$ & & \\
\hline Kwarc autigeniczny & $-0,26$ & 0,26 & 0,25 & 0,08 & $-0,21$ & 0,17 & $-0,27$ & 0,00 & $\mathrm{x}$ & \\
\hline Porowatość & 0,30 & 0,24 & 0,00 & 0,25 & 0,06 & 0,19 & $-0,45$ & $-0,17$ & $-0,05$ & $\mathrm{x}$ \\
\hline GSS & $-0,32$ & $-0,34$ & $-0,23$ & 0,22 & 0,60 & 0,15 & $-0,01$ & 0,00 & $-0,31$ & $-0,01$ \\
\hline GSO & $-0,08$ & 0,10 & 0,36 & 0,02 & 0,00 & $-0,08$ & 0,05 & $-0,20$ & 0,01 & $-0,26$ \\
\hline GSK & 0,26 & $-0,08$ & $-0,26$ & $-0,10$ & $-0,30$ & 0,06 & 0,06 & 0,16 & 0,04 & 0,09 \\
\hline GSP & $-0,27$ & $-0,05$ & 0,13 & 0,14 & 0,30 & $-0,02$ & $-0,07$ & $-0,10$ & 0,07 & $-0,11$ \\
\hline
\end{tabular}

Otrzymuje się w ten sposób niezwykle bogaty zestaw danych stanowiących wartościowy wkład do konstrukcji cyfrowych modeli 3D. Modele takie pozwalają na nowe spojrzenie na znany poniekąd obszar poszukiwań i określenie potencjalnych miejsc, w których odkrycie nowych złóż (zwłaszcza niekonwencjonalnych typu tight gas) jest najbardziej prawdopodobne. 


\section{Podsumowanie}

1. Wśród utworów czerwonego spągowca spotyka się szereg typów litologicznych. Są to głównie arenity (kwarcowe, subarkozowe, sublityczne i lityczne), a rzadziej bogatsze w ilasto-żelazistą matriks waki (kwarcowe, subarkozowe i sublityczne).

2. W składzie szkieletu ziarnowego dominuje kwarc (monokrystaliczny i polikrystaliczny). Drugim istotnym jego składnikiem są okruchy skał magmowych (granitoidy, ryolity, dacyty), metamorficznych (łupki kwarcowo-łyszczykowe, kwarcyty) i osadowych (piaskowce, mułowce, iłowce). Stosunkowo często obecne są także ziarna skaleni (potasowe - mikroklin, plagioklazy - albit, oligoklaz). Spotyka się również łyszczyki (muskowit) oraz minerały akcesoryczne (cyrkon, turmalin, apatyt) i nieprzeźroczyste (tlenki żelaza).

3. W przestrzeni porowej analizowanych skał wyróżnić można szereg różnego typu spoiw, m.in. ilasto-żelazistą matriks oraz cementy: ilasty, węglanowy, siarczanowy i kwarcowy.

4. Wśród osadów fluwialnych obserwuje się zdecydowanie zwiększoną zawartość litoklastów skał magmowych (wulkanicznych i głębinowych). Udział ilasto-żelazistej matriks jest zdecydowanie największy w osadach jeziornych (plaja). Osady facji białego spągowca wyróżniają się na tle innych największą średnią zawartością siarczanów, a także najmniejszym średnim udziałem matriks oraz cementu kwarcowego.

5. Analizowane skały charakteryzują się zmiennym udziałem porowatości - od bliskiej zeru do $20,5 \%$ obj. Największą średnią porowatość zaobserwowano w obrębie facji białego spągowca i facji eolicznej, najmniejszą natomiast dla utworów plai.

6. Utwory czerwonego spągowca uległy szeregowi procesów diagenetycznych (kompakcja, cementacja, rozpuszczanie, zastępowanie, przeobrażanie), spośród których na redukcję pierwotnej porowatości największy wpływ miały kompakcja i cementacja. Najczęściej kompakcja dominowała nad cementacja - sytuacja taka jest najbardziej widoczna w przypadku utworów facji fluwialnej, a najmniej dostrzegalna dla utworów jeziornych.

7. Wśród przeanalizowanych utworów czerwonego spągowca zdecydowanie dominują piaskowce średnioziarniste oraz drobnoziarniste, podczas gdy inne granulacje nie przekraczają 1\%. Stopień wysortowania ziaren przeważnie jest umiarkowanie dobry, przy czym znaczny udział mają również utwory o umiarkowanym oraz dobrym stopniu wysortowania. Zdecydowanie mniej liczne są przypadki, gdzie parametr ten odpowiada słabemu wysortowaniu.

8. Utwory eoliczne w głównej mierze są utworami zarówno drobno- jak i bardzo drobnoziarnistymi. Skały bardzo drobnoziarniste zdecydowanie przeważają w facji fluwialnej oraz jeziornej (plaja). Większe średnice (utwory drobnoziarniste) dominują natomiast w przypadku utworów białego spągowca.

9. Utwory eoliczne wykazują przewagę skał o umiarkowanie dobrym stopniu wysortowania, przy czym próbki o dobrym i umiarkowanym wysortowaniu również występują dość licznie. Utwory fluwialne są przeważnie dobrze bądź umiarkowanie dobrze wysortowane, co jest zjawiskiem zbliżonym do utworów białego spągowca. Skały powstałe w środowisku jeziornym wykazują największy wśród przebadanych próbek udział ziaren umiarkowanie dobrze wysortowanych.

10. Na podstawie korelacji wyników pomiarów granulometrycznych i petrograficznych można wyciągnąć wnioski, że w obrębie badanych utworów zachodzą zauważalne relacje, np. wraz ze wzrostem zawartości matriks ilasto-żelazistej oraz spadkiem wielkości ziaren udział kwarcu maleje; porowatość rośnie wraz ze wzrostem zawartości kwarcu; udział matriks rośnie wraz ze zmniejszaniem się średniej średnicy; zawartość skaleni jest powiązana z udziałem litoklastów; wzrost zawartości węglanów powoduje spadek porowatości.

Prosimy cytować jako: Nafta-Gaz 2016, nr 7, s. 502-512, DOI: 10.18668/NG.2016.07.02

Artykuł nadesłano do Redakcji 2.02.2016 r. Zatwierdzono do druku 12.04.2016 r.

Artykuł powstał na podstawie pracy statutowej pt. Warunki oraz możliwości występowania niekonwencjonalnych złóż gazu ziemnego zamkniętego w piaskowcach polskiego basenu czerwonego spagowca - praca INiG - PIB na zlecenie MNiSW; nr zlecenia: 0088/SG/2015, nr archiwalny: DK-4100-89/15.

\section{Literatura}

[1] Amthor J. E., Okkerman J.: Influence of early diagenesis on reservoir quality of Rotliegende sandstones, northern Netherlands. AAPG Bulletin 1998, vol. 82, nr 12, s. 2246-2265.

[2] Biernacka J., Leśniak G., Buniak A.: Wpływ kompakcji i cemen- tacji na właściwości zbiornikowe piaskowców eolicznych czerwonego spagowca z obszaru monokliny przedsudeckiej. Prace IGNiG 2006, vol. 134, s. 1-67.

[3] Buniak A., Mikołajewski Z.: Środowiska depozycyjne, petrografia 
i diageneza osadów czerwonego spagowca w rejonie Poznania Geologos 1997, vol. 2, s. 201-214.

[4] Darłak B., Kowalska-Włodarczyk M., Kobyłecka A., Leśniak G., Such P.: Przeglad wyników badań wtaściwości zbiornikowych i filtracyjnych wybranych skat zbiornikowych basenów młodopaleozoicznych Niżu Polskiego. Prace Państwowego Instytutu Geologicznego 1998, vol. 165, s. 147-153.

[5] Deczkowski Z.: Budowa geologiczna pokrywy permsko-mezozoicznej i jej podtoża we wschodniej części monokliny przedsudeckiej (obszar kalisko-częstochowski). Prace Instytutu Geologicznego 1977, vol. 82, s. 1-63.

[6] Folk R. L, Ward W. C.: Brazos River bar: a study in the significance of grain size parameters. Journal of Sedimentary Petrology 1957, vol. 27, s. 3-26.

[7] Gaupp R., Matter A., Platt J., Ramseyer K., Walzebuck J.: Diagenesis and fluid evolution of deeply buried Permian (Rotliegende) gas reservoirs, Northwest Germany. AAPG Bulletin 1993, vol. 77 , nr 7, s. 1111-1128.

[8] Grabowska-Olszewska B.: Mikrostruktury skat górnego czerwonego spagowca rejonu Bogdaj-Uciechów (monoklina przedsudecka) badane za pomoca elektronowego mikroskopu skaningowego (EMS). Biuletyn Geologiczny 1974, vol. 17, s. 57-72.

[9] Grabowska-Olszewska B., Chlebowski R., Kozłowski K., Kulesza-Wiewióra K., Myślińska E.: Litologia skat górnego czerwonego spagowca rejonu Bogdaj-Uciechów (monoklina przedsudecka). Biuletyn Geologiczny 1974, vol. 17, s. 5-55.

[10] Gregosiewicz Z., Protas A.: Facje, diageneza a właściwości zbiornikowe piaskowców czerwonego spagowca rejonu złoża Radlin. Nafta-Gaz 1997, nr 9, s 375-387.

[11] Karnkowski P. H.: Origin and evolution of the Polish Rotliegend Basin. Polish Geological Institute Special Papers 1999, vol. 3, s. 3-93.

[12] Kiersnowski H.: Architektura depozycyjna basenu czerwonego spagowca $w$ Polsce. [W:] Analiza basenów sedymentacyjnych Niżu Polskiego. Prace Państwowego Instytutu Geologicznego 1998, vol. 165, s. 113-128.

[13] Kuberska M.: Diageneza osadów czerwonego spagowca w strefie Szczecinek-Bydgoszcz (Pomorze Zachodnie). Biuletyn Państwowego Instytutu Geologicznego 2004, vol. 411, s. 87-168.

[14] Kuberska M.: Spoiwa weglanowe skat klastycznych czerwonego spagowca $w$ kujawsko-pomorskim segmencie strefy T-T. Przegląd Geologiczny 1999, vol. 47, nr 2, s. 159-162.

[15] Kuberska M., Maliszewska A., Grotek I.: Diageneza a rozwój przestrzeni porowej w piaskowcach górnego czerwonego spqgowca Pomorza Zachodniego. Biuletyn Państwowego Instytutu Geologicznego 2008, vol. 430, s. 43-64.

[16] Kwolek K., Buniak A.: Charakterystyka geologiczna i potencjat akumulacyjny utworów górnego czerwonego spagowca w rejonie Poznań-Ostrów Wlkp. [W:] Basen permski Niżu Polskiego. Czerwony Spagowiec. Budowa i potencjat zasobowy. Materiały z konferencji 2004, Piła, s. 47-60.

[17] Lanson B., Beaufort D., Berger G., Baradat J., Lacharpagne J.C.: Illitization of diagenetic kaolinite-to-dickite conversion series: late-stage diagenesis of the Lower Permian Rotliegend sandstone reservoir, offshore of the Netherlands. Journal of Sedimentary Research 1996, vol. 66, nr 3, s. 501-518.

[18] Lorenc S., Muszyński A., Protas A., Ziółkowska M.: Litogeneza osadów czerwonego spagowca podłoża Wielkopolski. [W:] Przewodnik 62. Zjazdu Polskiego Towarzystwa Geologicznego 1991, s. 127-128.

[19] Lundegard P. D.: Sandstone porosity loss - A , big picture” view of the importance of compaction. Journal of Sedimentary Petrology 1992, vol. 62, nr 2, s. 250-260.

[20] Maliszewska A.: K/Ar age of the fibrous illite of Rotliegend sandstone in Wielkopolska region. [W:] IV Ogólnopolska Sesja Naukowa „Datowanie Minerałów i Skał”. Uniwersytet Marii Curie-Skłodowskiej. Lublin 1997, s. 50-55.
[21] Maliszewska A.: O znaczeniu badań izotopowych diagenetycznego illitu z piaskowców czerwonego spagowca. Przeglad Geologiczny 1999, vol. 47, s. 476.

[22] Maliszewska A., Kiersnowski H., Kuberska M., Kozłowska A., Sikorska M., Jarmołowicz-Szulc K.: Litofacje i właściwości zbiornikowe piaskowców czerwonego spagowca górnego na obszarze monokliny przedsudeckiej. Opracowanie archiwalne. CAG Państwowy Instytut Geologiczny. Warszawa 2008.

[23] Maliszewska A., Kuberska M.: Cementacja piaskowców czerwonego spagowca a ich porowatość i przepuszczalność. Nafta-Gaz 1996, vol. 52, nr 9, s. 365-373.

[24] Maliszewska A., Kuberska M., Such P., Leśniak G.: Ewolucja przestrzeni porowej utworów czerwonego spagowca. Prace Państwowego Instytutu Geologicznego 1998, vol. 165, s. 171-184.

[25] Maliszewska A., Kuberska M.: Rozwój diagenezy osadów górnego czerwonego spagowca z otworów Objezierze IG1, Września IG1, Zakrzyń IG1. [W:] Nowa strategia i perspektywy poszukiwań złóż gazu ziemnego w osadach czerwonego spagowca. Projekt celowy 40 Departamentu Badań Naukowych Ministerstwa Edukacji i Nauki. Archiwum AGH. Kraków 2005.

[26] McNeil B., Shaw H. F., Rankin A. H.: The timing of cementation in the Rotliegend sandstones of the Southern North Sea: A petrological and fluid inclusion study of cements. Journal of Petroleum Geology 1998, vol. 21, nr 3, s. 311-327.

[27] Michalik M.: Diagenesis of the Weissliegend sandstones in the south-western margin of the Polish Rotliegend Basin. Prace Mineralogiczne 2001, vol. 91, s. 1-176.

[28] Papiernik B., Górecki W., Pasternacki A.: Wstępne wyniki modelowań przestrzennych (3D) parametrów petrofizycznych skat podczas poszukiwań stref wystepowania gazu zamkniętego $w$ polskim basenie czerwonego spagowca. Przegląd Geologiczny 2010, vol. 58 , nr 4, s. 352-364.

[29] Pokorski J.: Perspektywy wystepowania złóż gazu ziemnego w utworach czerwonego spagowca. Prace Państwowego Instytutu Geologicznego 1998, vol. 165, s. 293-298.

[30] Rochewicz A.: Wplyw procesów illityzacji i chlorytyzacji na własności zbiornikowe piaskowców czerwonego spagowca SW Polski. Archiwum Mineralogiczne 1980, vol. 36, nr 2, s. 55-64.

[31] Such P.: Model fizyczny przestrzeni filtracji basenu czerwonego spagowca. Prace Instytutu Górnictwa Naftowego i Gazownictwa 1996, nr 88, s. 1-82.

[32] Udden J. A.: Mechanical composition of clastic sediments. Bulletin of the Geological Society of America 1914, vol. 25, s. 655-744.

[33] Wentworth C. K.: A scale of grade and class terms for clastic sediments. Journal of Geology 1922, vol. 30, s. 377-392.

[34] Wolnowski T.: Prognoza zasobności czerwonego spagowca w basenie permskim Niżu Polskiego w świetle nowych technik poszukiwawczych. [W:] Basen permski Niżu Polskiego. Czerwony Spagowiec. Budowa i potencjat zasobowy. Materiały z konferencji 2004, Piła, s. 17-30.

[35] Zwingmann H., Clauer N., Gaupp R.: Timing of fluid in a sandstone reservoir of the north German Rotliegend (Permian) by $K-$ Ar dating of related hydrothermal illite. In: Dating and duration of fluid flow and fluid rock interaction. Geological Society Special Publication 1998, vol. 144, s. 91-106.

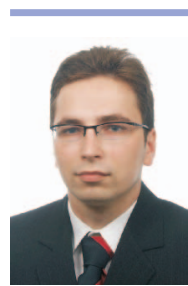

Mgr Konrad ZIEMIANIN

Asystent w Zakładzie Geologii i Geochemii. Instytut Nafty i Gazu - Państwowy Instytut Badawczy ul. Lubicz 25 A

31-503 Kraków

E-mail:konrad.ziemianin@inig.pl 